\title{
Physical, Thermal, and Spectroscopic Characterization of Biofield Energy Treated Murashige and Skoog Plant Cell Culture Media
}

\author{
Mahendra Kumar Trivedi ${ }^{1}$, Alice Branton ${ }^{1}$, Dahryn Trivedi ${ }^{1}$, Gopal Nayak ${ }^{1}$, Khemraj Bairwa ${ }^{2}$, \\ Snehasis Jana ${ }^{2, *}$ \\ ${ }^{1}$ Trivedi Global Inc., Henderson, USA \\ ${ }^{2}$ Trivedi Science Research Laboratory Pvt. Ltd., Bhopal, Madhya Pradesh, India
}

Email address:

publication@trivedisrl.com (S. Jana)

\section{To cite this article:}

Mahendra Kumar Trivedi, Alice Branton, Dahryn Trivedi, Gopal Nayak, Khemraj Bairwa, Snehasis Jana. Physical, Thermal, and Spectroscopic Characterization of Biofield Energy Treated Murashige and Skoog Plant Cell Culture Media. Cell Biology. Vol. 3, No. 4, 2015, pp. 50-57. doi: 10.11648/j.cb.20150304.11

\begin{abstract}
The Murashige and Skoog medium (MS media) is a chemically defined and widely used as a growth medium for plant tissue culture techniques. The present study was attempted to evaluate the impact of biofield energy treatment on the physical, thermal, and spectral properties of MS media. The study was performed in two groups; one was kept as control while another was subjected to Mr. Trivedi's biofield energy treatment and coded as treated group. Afterward, both the control and treated samples were analyzed using various analytical techniques. The X-ray diffraction (XRD) analysis showed $19.92 \%$ decrease in the crystallite size of treated sample with respect to the control. The thermogravimetric analysis (TGA) showed the increase in onset temperature of thermal degradation ( $\left.\mathrm{T}_{\text {onset }}\right)$ by $9.41 \%$ and $10.69 \%$ in first and second steps of thermal degradation, respectively after the biofield energy treatment as compared to the control. Likewise, $\mathrm{T}_{\max }$ (maximum thermal degradation temperature) was increased by $17.43 \%$ and $28.61 \%$ correspondingly in the first and second step of thermal degradation in the treated sample as compared to the control. The differential scanning calorimetry (DSC) analysis indicated the $143.51 \%$ increase in the latent heat of fusion of the treated sample with respect to the control sample. The Fourier transform infrared spectroscopy (FT-IR) spectrum of treated MS media showed the alteration in the frequency such as $3165 \rightarrow 3130 \mathrm{~cm}^{-1}$ (aromatic C-H stretching); $2813 \rightarrow 2775 \mathrm{~cm}^{-1}$ (aliphatic C-H stretching); $1145 \rightarrow 1137 \mathrm{~cm}^{-1}$ (C-N stretching), $995 \rightarrow 1001 \mathrm{~cm}^{-1}$ ( $\mathrm{S}=\mathrm{O}$ stretching), etc. in the treated sample with respect to the control. The UV spectra of control and treated MS media showed the similar absorbance maxima $\left(\lambda_{\max }\right)$ i.e. at 201 and $198 \mathrm{~nm}$, respectively. The XRD, TGA-DTG, DSC, and FT-IR results suggested that Mr. Trivedi's biofield energy treatment has the impact on physical, thermal, and spectral properties of the MS media. As a result, the treated MS media could be more stable than the control, and might be used as better media in the plant tissue culture technique.
\end{abstract}

Keywords: Biofield Energy Treatment, Murashige and Skoog Medium, X-ray Diffraction, Fourier Transform Infrared Spectroscopy

\section{Introduction}

The optimum growth and development of plant tissues are vary among the plants according to their nutritive requirements [1]. The tissues from different plant parts may also have different requirements for appropriate growth. Furthermore, the plant species are sensitive to growth regulators and high salts [2]. Therefore, the tissue culture medium was selected based on the species to be cultured.
Development of culture medium was a consequence of several systematic experimentation and trials [2,3]. An ideal plant tissue culture media should contain the constituents such as micronutrients $(<0.5 \mathrm{mM} / \mathrm{L})$, macronutrients $(>0.5$ $\mathrm{mM} / \mathrm{L}$ ), amino acids, nitrogen supplements, vitamins, carbon source, undefined organic supplements, plant growth regulators and solidifying agents such as agar $[4,5]$. The Murashige and Skoog media (MS media) is a chemically defined and most suitable classic plant cell culture medium, consisting vitamins, carbohydrates, and inorganic salts [6]. 
Ammonium nitrate and potassium nitrate serves as the nitrogen sources, while sucrose was used as the source of carbohydrate. The MS medium was first invented by Toshio Murashige and Folke Skoog to support the tobacco callus and regeneration of shoots and plantlets from the explants $[6,7]$. Autoclaving or heat treatment is the standard method of culture media sterilization [8]. However, the extensive heat treatment of complex culture media may result in nutrient destruction via the direct thermal degradation or chemical reactions between the components [9]. Therefore, it is advantageous to find out an alternative approach that can enhance the thermal stability of culture media.

Recently, the energy therapies have been reported for several beneficial effects throughout the world. Biofield energy treatment is the part of energy therapy that has been reported to alter the numerous physicochemical and spectral properties of organic compounds [10] and organic products [11]. The National Institute of Health/National Center for Complementary and Alternative Medicine (NIH/NCCAM) considered the healing energy or the putative energy fields treatment under the subcategory of energy therapies [12]. The energy therapies such as magnet therapy, bio-electromagnetic therapy, healing touch, etc. comprise low-level of energy field interactions [13]. Numerous mechanism and explanations are proposed in support of the biofield energy therapies including the consciousness. It is described as healer's intent to heal, which may interact with the physical realm [14]. Similarly, physical resonance is another concept that includes subtle energies. According to this, the energy might exchange between the energy fields of patient and therapist [15]. Thus, the human can harness the energy from Universe and transmit it to the objects (living or non-living). The objects receive this energy and respond in a useful way. This process is called as biofield energy treatment. Mr. Trivedi is well known for his unique biofield energy treatment (The Trivedi Effect ${ }^{\circledR}$ ) that has been studied in the field of biotechnology [16], agricultural science [17], microbiology [18], etc.

Therefore, after considering the significant impact of biofield energy treatment in different areas, this study was attempted to evaluate its impact on the plant cell culture media such as MS media. The biofield energy treated MS media, and the respective control sample were analyzed using several analytical techniques such as X-ray diffractometry (XRD), thermogravimetric analysis-derivative thermogravimetry (TGA-DTG), Differential scanning calorimetry (DSC), Fourier transform infrared (FT-IR) spectroscopy, and ultraviolet-visible (UV-vis) spectroscopy.

\section{Materials and Methods}

\subsection{Study Design}

The MS media was procured from HiMedia Laboratories, India. It contained several inorganic salts such as ammonium nitrate, EDTA, ferrous sulphate, magnesium sulphate, myoinositol, potassium nitrate, potassium phosphate, sucrose, etc.
(Table 1). The MS media was divided into two groups; one was kept as control while another was handed over to $\mathrm{Mr}$. Trivedi to render the biofield energy treatment under standard laboratory conditions. Mr. Trivedi provided the biofield energy treatment to the treated group via his unique energy harnessing process without touching the sample. Subsequently, both the control and treated samples were analyzed with respect to physicochemical and spectroscopic properties using various analytical techniques such as XRD, TGA-DTG, DSC, FT-IR, and UV-vis spectroscopy.

Table 1. Chemical composition of Murashige and Skoog media.

\begin{tabular}{lll}
\hline S. No. & Ingredients & $\mathbf{m g} / \mathbf{L}$ \\
\hline 1 & Ammonium nitrate & 1650.000 \\
2 & Boric acid & 6.200 \\
3 & Cobalt chloride. $6 \mathrm{H}_{2} \mathrm{O}$ & 0.025 \\
4 & Copper sulphate. $5 \mathrm{H}_{2} \mathrm{O}$ & 0.025 \\
5 & EDTA disodium salt. $2 \mathrm{H}_{2} \mathrm{O}$ & 37.300 \\
6 & Ferrous sulphate. $7 \mathrm{H}_{2} \mathrm{O}$ & 27.800 \\
7 & Glycine (Free base) & 2.000 \\
8 & Magnesium sulphate & 180.690 \\
9 & Manganese sulphate. $\mathrm{H}_{2} \mathrm{O}$ & 16.900 \\
10 & Molybdic acid (sodium salt) $2 \mathrm{H}_{2} \mathrm{O}$ & 0.250 \\
11 & myo-Inositol & 100.000 \\
12 & Nicotinic acid (Free acid) & 0.500 \\
13 & Potassium iodide & 0.830 \\
14 & Potassium nitrate & 1900.000 \\
15 & Potassium phosphate monobasic & 170.000 \\
16 & Pyridoxine hydrochloride & 0.500 \\
17 & Sucrose & 30000.000 \\
18 & Thiamine hydrochloride & 0.100 \\
19 & Zinc sulphate.7 $\mathrm{H}_{2} \mathrm{O}$ & 8.600 \\
\hline
\end{tabular}

\subsection{XRD Study}

The XRD analysis of control and treated samples of MS media was done on PW 1710 Phillips Holland X-ray diffractometer with copper anode and nickel filter. The wavelength of XRD system was set to $1.54056 \AA$. The percent change in crystallite size (G) was calculated using following equation:

$$
\mathrm{G}=\left[\left(\mathrm{G}_{\mathrm{T}}-\mathrm{G}_{\mathrm{C}}\right) / \mathrm{G}_{\mathrm{C}}\right] \times 100
$$

Here, $G_{T}$ and $G_{C}$ are the crystallite size of treated and control samples, respectively.

\subsection{TGA-DTG Analysis}

The TGA-DTG analysis of control and treated samples was carried out on Mettler Toledo simultaneous TGA/DTG $\mathrm{STAR}^{\mathrm{e}} \mathrm{SW} 8.10$ thermal analyzer. The analytes were heated up to $400^{\circ} \mathrm{C}$ from room temperature at the heating rate of $5^{\circ} \mathrm{C} / \mathrm{min}$ under air atmosphere. The onset temperature of thermal degradation $\left(\mathrm{T}_{\text {onset }}\right)$ and the temperature at which maximum weight loss occur $\left(\mathrm{T}_{\max }\right)$ were obtained from TGADTG thermograms.

\subsection{DSC Study}

The melting temperature and latent heat of fusion of control and treated MS media were determined using the Pyris-6 Perkin Elmer differential scanning calorimeter. The 
samples were heated up to $300^{\circ} \mathrm{C}$ at the heating rate of $10^{\circ} \mathrm{C} / \mathrm{min}$ under air atmosphere with air flow rate of 5 $\mathrm{mL} / \mathrm{min}$.

\subsection{FT-IR Spectroscopic Characterization}

The FT-IR spectroscopic analysis of control and treated samples of MS media was carried out on Shimadzu's Fourier transform infrared spectrometer (Japan) in the frequency region of $500-4000 \mathrm{~cm}^{-1}$. The samples for FT-IR analysis were prepared by mixing of MS media sample (1\%) with $\mathrm{KBr}$ powder and then pressed to a disc or pellets.

\subsection{UV-Vis Spectroscopic Analysis}

The UV-vis spectra of control and treated MS media were recorded on Shimadzu's UV spectrometer (2400 PC). The instrument was equipped with quartz cell of $1 \mathrm{~cm}$ with a slit width of $2.0 \mathrm{~nm}$. The samples were analyzed at the UV wavelength region of $200-400 \mathrm{~nm}$.

\section{Results and Discussion}

\subsection{XRD Analysis}
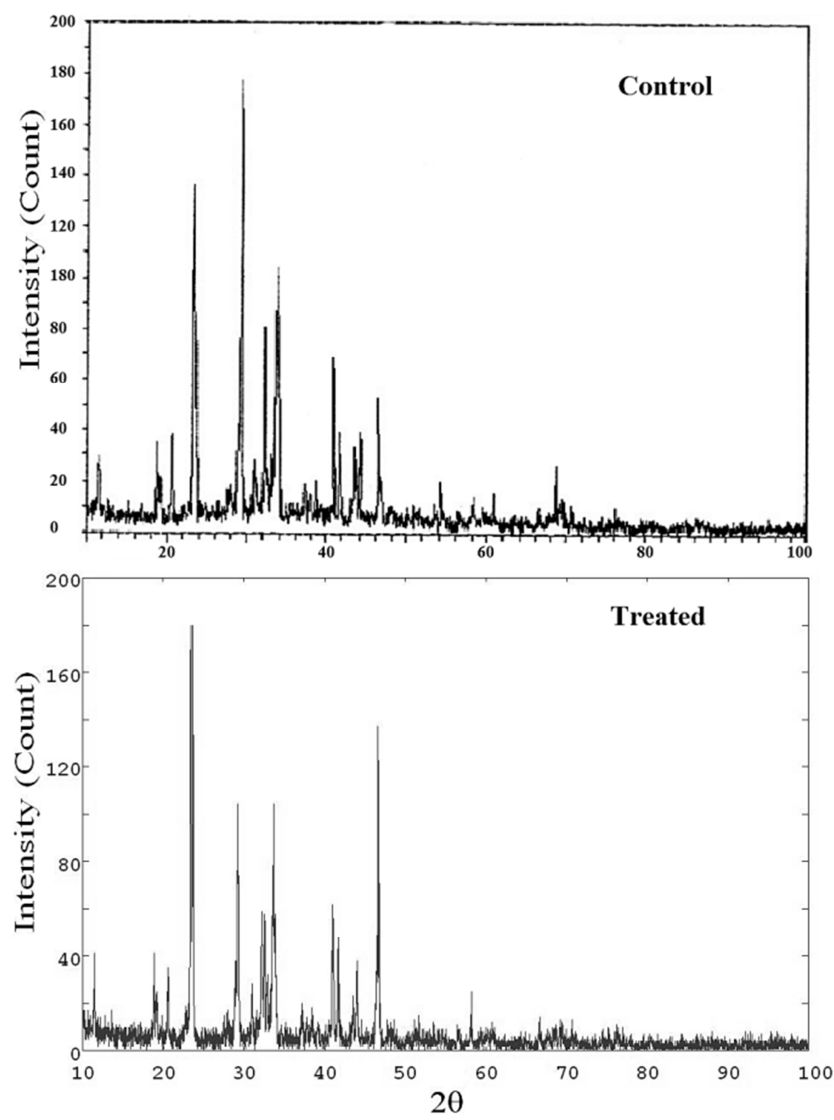

Fig. 1. XRD diffractograms of control and treated Murashige and Skoog media.

The XRD diffractograms of control and treated MS media are shown in Fig. 1. The XRD diffractograms showed the sharp and intense peaks in both the samples. This suggested the crystalline nature of control and treated MS media. The
XRD diffractogram of control MS media showed the peaks at Bragg's angle $(2 \theta)$ equal to $23.35^{\circ}, 29.29^{\circ}, 32.25^{\circ}, 33.67^{\circ}$, and $40.92^{\circ}$. Similarly, the XRD diffractogram of treated MS media exhibited the XRD peaks at $2 \theta$ equal to $23.39^{\circ}, 23.69^{\circ}$, $29.28^{\circ}, 33.67^{\circ}$, and $46.64^{\circ}$. The result showed that positions of XRD peaks in biofield energy treated sample were slightly altered with respect to the control sample peaks. It is reported that due to the presence of internal strain within the molecules the positions and shape of X-ray diffraction peaks can alter [19]. Based on this, it is hypothesized that the biofield energy treatment possibly produced some internal strain within the treated sample. Furthermore, the average crystallite sizes of both the samples were determined using Scherrer equation [20].

The result exhibited the crystallite size of the control and treated samples as 95.53 and $76.25 \mathrm{~nm}$, respectively. The result showed $19.92 \%$ decrease in the crystallite size of treated sample as compared to the control (Fig. 2). It was reported that increase in lattice strain may reduce the crystallite size of the sample $[21,22]$. Therefore, it presumed that biofield energy had induced some lattice strain within the treated molecules of MS media. As a result, the grains were fractured into sub grains that could lead to decrease the crystallite size of the treated sample as compared to the control. This decrease in crystallite size of the treated sample might enhance its solubility as compared to the corresponding control during the preparation of culture media for plant tissue culture [23].

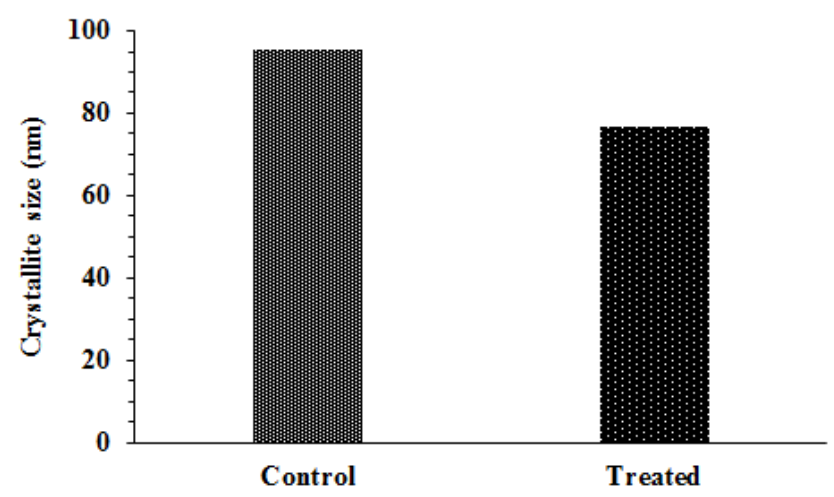

Fig. 2. Crystallite size of control and treated Murashige and Skoog media.

\subsection{TGA-DTG Analysis}

The TGA/DTG thermograms of control and treated MS media are shown in Fig. 3. The TGA thermogram of control sample showed the three steps of thermal degradation process. The first step was started at $85^{\circ} \mathrm{C}$ ( $\left.\mathrm{T}_{\text {onset }}\right)$ and terminated at $148^{\circ} \mathrm{C}\left(\mathrm{T}_{\text {endset }}\right)$ with $3.33 \%$ weight loss. During this phase, the maximum thermal degradation $\left(\mathrm{T}_{\max }\right)$ was observed at $120.5^{\circ} \mathrm{C}$. The second step was started from $159^{\circ} \mathrm{C}$ and terminated at $202^{\circ} \mathrm{C}$ with a percent weight loss of $12.24 \%$ and $\mathrm{T}_{\max }$ of $180^{\circ} \mathrm{C}$. Similarly, the third step was initiated at $210^{\circ} \mathrm{C}$ and terminated at $258^{\circ} \mathrm{C}$ with $\mathrm{T}_{\max }$ of $233^{\circ} \mathrm{C}$ and $12.6 \%$ of sample loss. The results exhibited a cumulative $28.17 \%$ weight loss during first, second and third steps of thermal degradation. On the other hand, the treated 
sample showed the two steps of thermal degradation. The first step was initiated at $93^{\circ} \mathrm{C}$, which was ended at $170^{\circ} \mathrm{C}$ with $9.05 \%$ weight loss and $\mathrm{T}_{\max }$ of $141.5^{\circ} \mathrm{C}$. The second step was initiated at $176^{\circ} \mathrm{C}$ and terminated at $245^{\circ} \mathrm{C}$ with $\mathrm{T}_{\max }$ of $231.5^{\circ} \mathrm{C}$, and $7.78 \%$ sample loss. This showed the cumulative $16.87 \%$ weight loss during the first and second steps of thermal degradation.

Overall, the TGA/DTG study revealed the increase in $\mathrm{T}_{\text {onset }}$ by $9.51 \%$ (in first step) and $10.69 \%$ (in second step) in the biofield energy treated sample as compared to the control.
Furthermore, the $\mathrm{T}_{\max }$ was increased by $17.43 \%$ and $28.61 \%$ in first and second steps of thermal degradation in treated sample with respect to the control. The increase in $\mathrm{T}_{\text {onset }}$ and $\mathrm{T}_{\max }$ of both the steps in treated sample suggested the increased thermal stability as compared to the control [24]. Further, the decreases in cumulative percent weight loss during the thermal degradation process in treated sample also suggested its enhanced thermal stability than the control [25, 26]. Based on this, it is assumed that the biofield treated MS media is thermally more stable than the control sample.
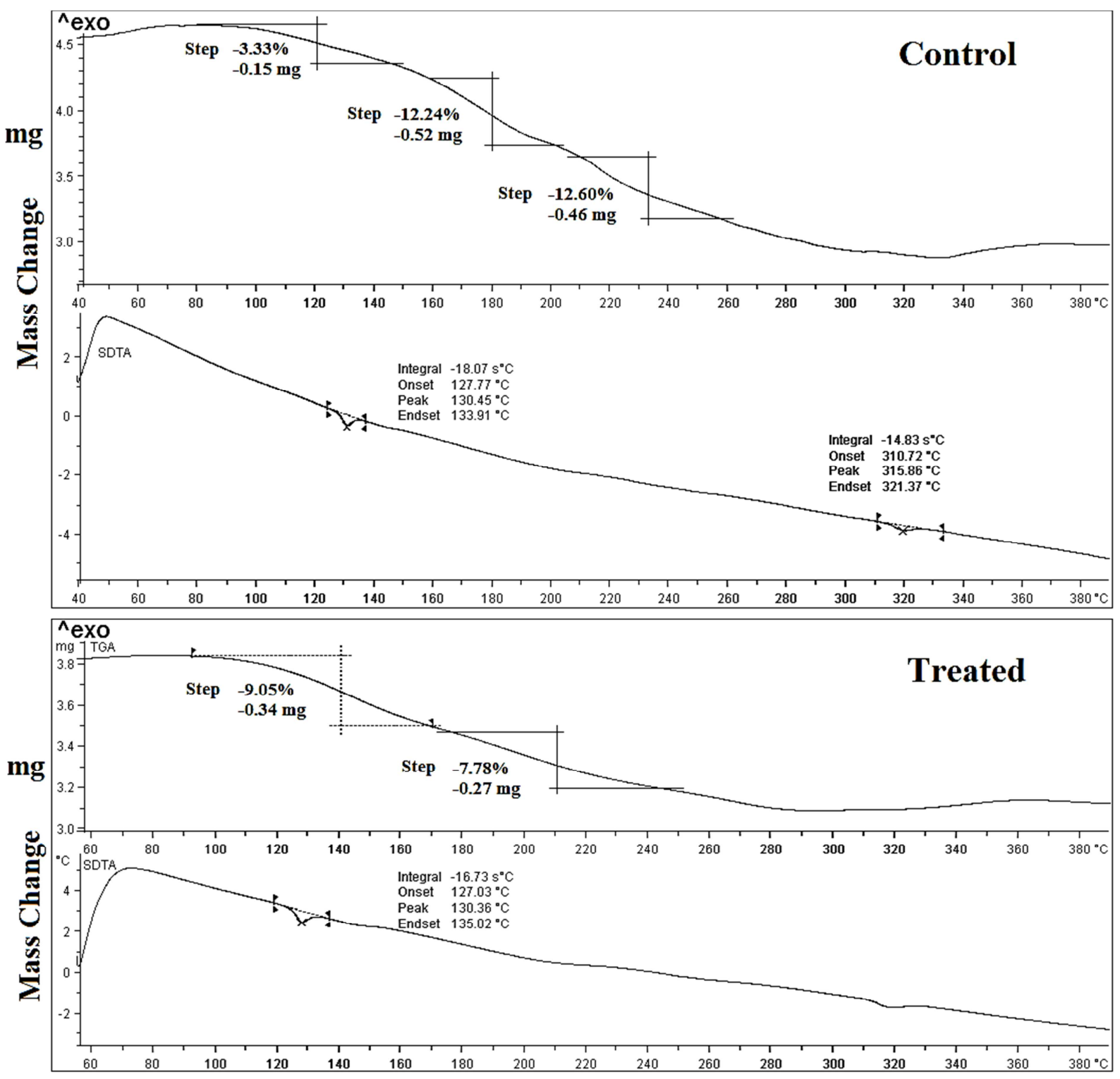

Fig. 3. TGA-DTG thermograms of control and treated Murashige and Skoog media.

\subsection{DSC Analysis}

The DSC analysis was performed to determine the latent heat of fusion $(\Delta \mathrm{H})$ and the melting temperature of both the control and treated MS media. A considerable amount of interaction force present in the chemical bonds of any substance holds them tightly on their positions. The energy required to overcome the interaction force during the phase change (i.e. solid into liquid) is termed as the $\Delta \mathrm{H}$. The DSC thermograms (Fig. 4) of MS media showed the latent heat of fusion as $28.68 \mathrm{~J} / \mathrm{g}$ in the control and $69.84 \mathrm{~J} / \mathrm{g}$ in the treated sample (Table 2). This showed about $143.51 \%$ increase in the latent heat of fusion of treated sample as compared to the control sample. It might be due to increase in intermolecular force after the biofield energy treatment of MS media than the corresponding control. Consequently, the treated MS 
media molecules absorbed more heat $(\Delta \mathrm{H})$ to change the phase from solid to liquid as compared to the control. Previously, our group has reported the biofield energy treatment induced alteration in $\Delta \mathrm{H}$ in organic products such as bile salt and proteose peptone [27]. Therefore, it is supposed that biofield treatment might increase the intermolecular interaction forces in treated MS media molecules, which may lead to increase its latent heat of fusion.

Moreover, the DSC thermograms of MS media exhibited the melting temperature at $132.21^{\circ} \mathrm{C}$ in control and $132.07^{\circ} \mathrm{C}$ in treated sample (Table 2 ). The result showed no significant change in the melting temperature of the treated sample with respect to the control.

Table 2. Thermal analysis of control and treated samples of Murashige and Skoog media.

\begin{tabular}{lll}
\hline Parameter & Control & Treated \\
\hline & 85.00 & 93.00 \\
Onset temperature $\left({ }^{\circ} \mathrm{C}\right)$ & 159.00 & 176.00 \\
& 210.00 & \\
& 120.50 & 141.50 \\
$\mathrm{~T}_{\max }\left({ }^{\circ} \mathrm{C}\right)$ & 180.00 & 231.50 \\
& 233.00 & \\
Latent heat of fusion $(\mathrm{J} / \mathrm{g})$ & 28.68 & 69.84 \\
Melting point $\left({ }^{\circ} \mathrm{C}\right)$ & 132.21 & 132.07 \\
\hline
\end{tabular}

$\mathrm{T}_{\max }$ : temperature at maximum weight loss occurs.
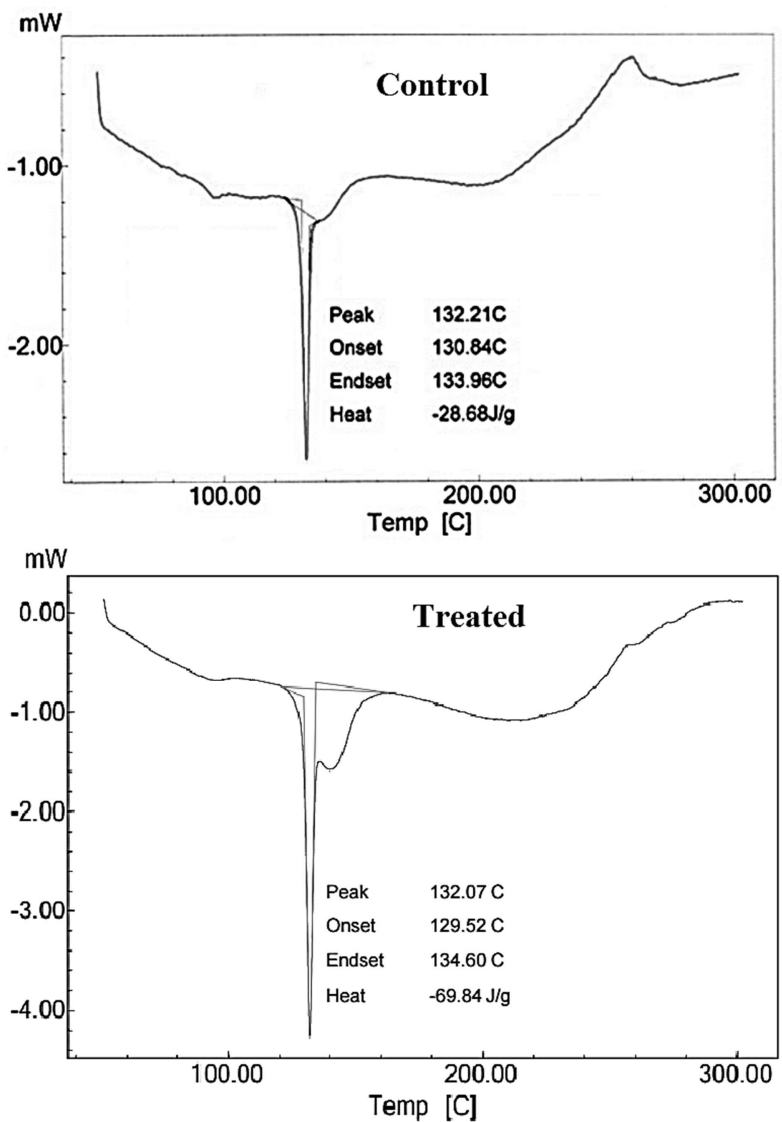

Fig. 4. DSC thermograms of control and treated Murashige and Skoog media.

\subsection{FT-IR Spectroscopic Analysis}

FT-IR spectra of the control and treated MS media are shown in Fig. 5. The contents like inorganic salt, plant growth regulators, and carbohydrates comprised in MS media may contain functional groups such as $\mathrm{O}-\mathrm{H}, \mathrm{N}-\mathrm{H}, \mathrm{C}-\mathrm{H}, \mathrm{C}=\mathrm{C}, \mathrm{N}=\mathrm{O}$, $\mathrm{C}-\mathrm{O}$, etc. Therefore, the FT-IR spectra of MS media may be expected with the vibrational frequencies associated with these groups. The vibration peak at $3546 \mathrm{~cm}^{-1}$ in control and 3543 $\mathrm{cm}^{-1}$ in treated sample were assigned to $\mathrm{O}-\mathrm{H}$ stretching. The vibration peak at $3165 \mathrm{~cm}^{-1}$ in control sample was assigned to aromatic $\mathrm{C}-\mathrm{H}$ stretching that was shifted to lower frequency region i.e. at $3130 \mathrm{~cm}^{-1}$ after the biofield energy treatment. The position of IR peak in the FT-IR spectrum depends on the force constant and the dipole moment of respective bond. The increase in dipole moment or force constant in the same atomic bond cause to increase in the frequency (upstream shift) and vice versa $[28,29]$. Based on this, it is hypothesized that the force constant or dipole moment of aromatic $\mathrm{C}-\mathrm{H}$ might decrease; therefore, the IR peak of aromatic $\mathrm{C}-\mathrm{H}$ was shifted to lower frequency region.

The IR peak at $2895 \mathrm{~cm}^{-1}$ in control sample was assigned to aliphatic $\mathrm{C}-\mathrm{H}_{3}$ stretching. This peak was shifted to $2902 \mathrm{~cm}^{-1}$ in the treated sample. Furthermore, the peak at $2813 \mathrm{~cm}^{-1}$ in control sample was assigned to aliphatic $\mathrm{C}-\mathrm{H}_{2}$, which was shifted to lower frequency region i.e. at $2775 \mathrm{~cm}^{-1}$ in the treated sample. This might be due to alteration in force constant or dipole moment of $\mathrm{CH}_{3}$ and $\mathrm{CH}_{2}$ group in treated sample with respect to the control. The IR peak at $1762 \mathrm{~cm}^{-1}$ in control and treated sample were assigned to $\mathrm{N}=\mathrm{O}$ stretching due to nitrate salt (ammonium nitrate or potassium nitrate) present in the sample.

In addition, the peaks at $1398 \mathrm{~cm}^{-1}$ in control and $1402 \mathrm{~cm}^{-1}$ in treated samples were assigned to asymmetric $\mathrm{NO}_{3}$ vibration. Likely, the IR peak at $825 \mathrm{~cm}^{-1}$ in both the control and treated sample was attributed to symmetric vibration of $\mathrm{NO}_{3}$ group, possibly due to nitrate salts [30]. The IR peak at $1626 \mathrm{~cm}^{-1}$ in control was assigned to $\mathrm{C}=\mathrm{C}$ stretching, which was slightly sifted to $1620 \mathrm{~cm}^{-1}$ in the treated sample. This showed the decrease in force constant of $\mathrm{C}=\mathrm{C}$ bond of treated sample as compared to the control. The peak at $1145 \mathrm{~cm}^{-1}$ in the control sample was assigned to $\mathrm{C}-\mathrm{N}$ stretching (might be due to EDTA) that was shifted to $1137 \mathrm{~cm}^{-1}$ in the treated sample. It suggested the reduction in force constant or dipole moment of $\mathrm{C}-\mathrm{N}$ bond after the biofield energy treatment as compared to the control. The IR peak at $995 \mathrm{~cm}^{-1}$ in control was attributed to $\mathrm{S}=\mathrm{O}$ stretching possibly due to presence of sulfates salts such as magnesium sulphate and manganese sulphate comprised in MS media [31]. This $\mathrm{S}=\mathrm{O}$ stretching peak was sifted to $1001 \mathrm{~cm}^{-1}$ in the treated sample. The IR peaks at $603-$ $663 \mathrm{~cm}^{-1}$ in control and $603-657 \mathrm{~cm}^{-1}$ in the treated sample were assigned to $\mathrm{C}-\mathrm{S}$ stretching, possibly due to thiamine hydrochloride, present in the MS media [32]. Overall, the FTIR data suggested that biofield energy treatment acted at the molecular level of treated MS media and altered the dipole moment or force constant with respect to the corresponding control sample. 

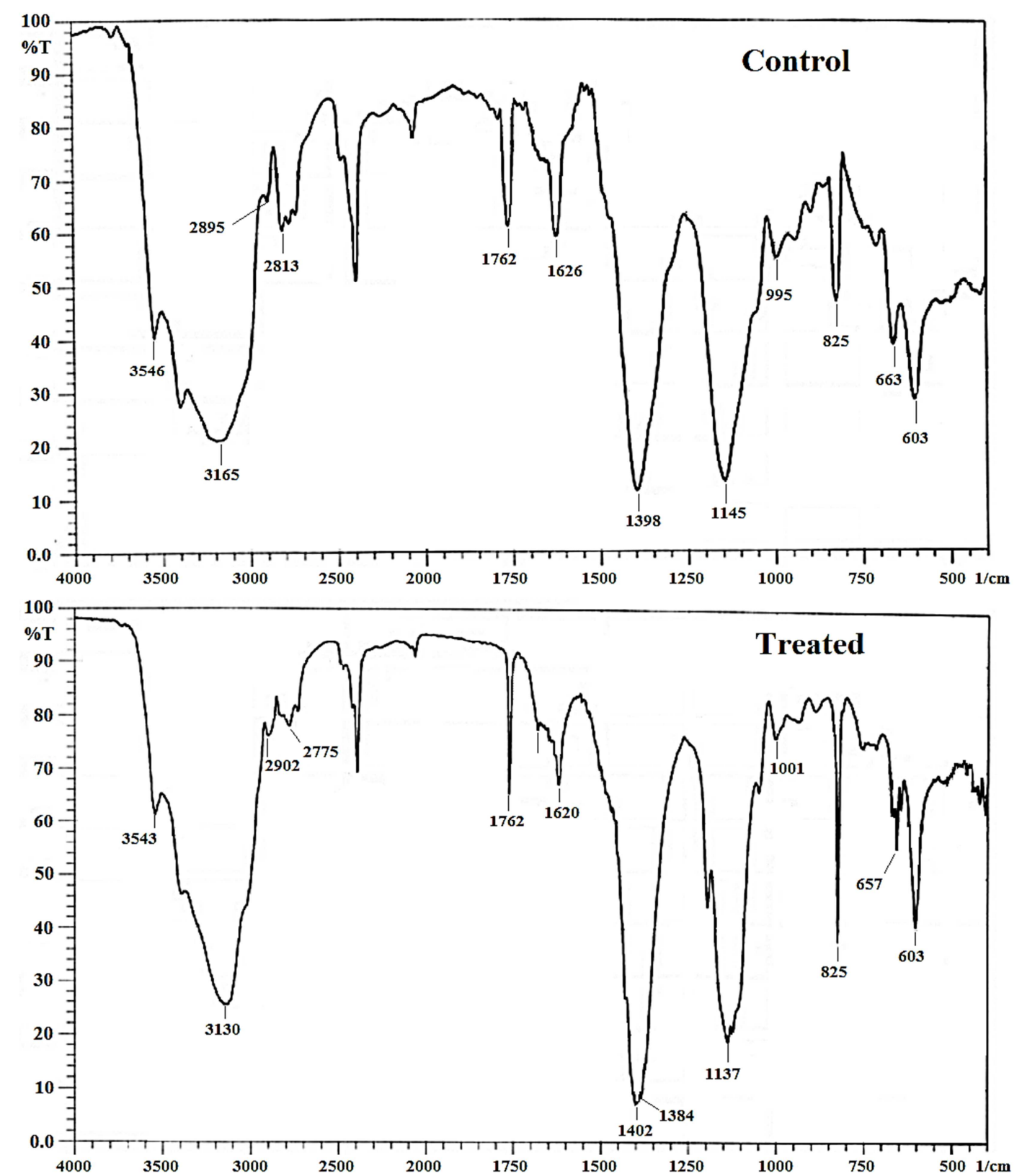

Fig. 5. FT-IR spectra of control and treated Murashige and Skoog media.

\subsection{UV-Vis Spectroscopic Characterization}

The UV spectra of both the control and treated MS media are shown in Fig. 6. It showed the absorbance maxima $\left(\lambda_{\max }\right)$ at $201 \mathrm{~nm}$ in control sample and $198 \mathrm{~nm}$ in treated sample. It is reported that the UV absorbance occurred due to excitation of electrons from highest energy occupied molecular orbital (HOMO) to lowest energy unoccupied molecular orbital (LUMO) [33]. However, the UV analysis of MS media showed no change in the $\lambda_{\max }$ of biofield treated sample as compared to the control. It indicated that energy gap between the HOMO and LUMO was not altered in the treated sample as compared to the control.

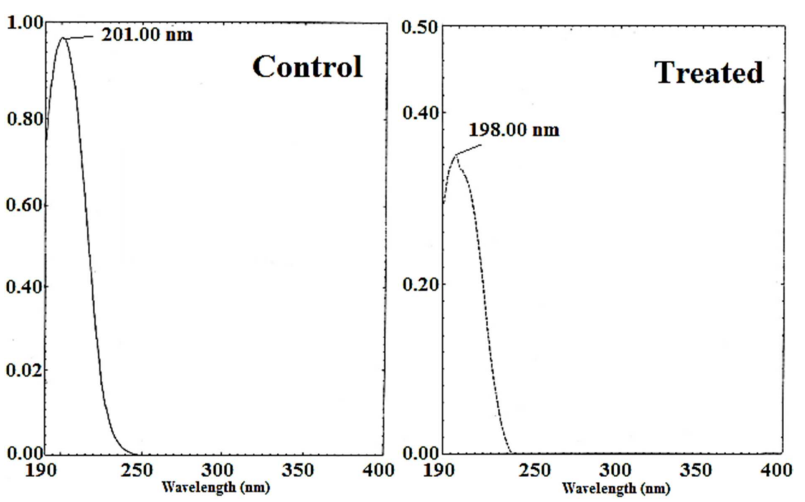

Fig. 6. UV spectra of control and treated MS media. 


\section{Conclusions}

The XRD study revealed the crystalline nature of both the control and treated samples. Moreover, the crystallite size of biofield treated sample was significantly decreased (19.92\%) as compared to the control. This might be due to the fracturing of grains into sub grains caused by biofield induced lattice strain in the treated MS media. The TGADTG study revealed the considerable increase of $\mathrm{T}_{\text {onset }}$ in treated sample by $9.41 \%$ (in first step) and $10.69 \%$ (in second step) as compared to the control. Similarly, $\mathrm{T}_{\max }$ was increased by $17.43 \%$ and $28.61 \%$ in first and second steps of thermal degradation, respectively in the treated sample as compared to the control. This showed the increase in the thermal stability of treated sample with respect to the control. The DSC analysis showed the $143.51 \%$ increase in the latent heat of fusion of treated sample as compared to the control sample. The FT-IR spectral analysis showed the alteration in the vibrational frequency of functional groups such as aromatic and aliphatic $\mathrm{C}-\mathrm{H}, \mathrm{C}=\mathrm{C}, \mathrm{C}-\mathrm{N}$, and $\mathrm{S}=\mathrm{O}$ in the treated sample with respect to the control. This might be due to alteration in the force constant or dipole moment of respective groups in treated sample as compared to the control.

Based on these results, it is suggested that Mr. Trivedi's biofield energy treatment has the significant impact on the physical, thermal and spectral properties of MS media. As a result, the treated MS media could be utilized as a better medium in the plant tissue culture.

\section{Abbreviations}

NIH: National Institute of Health; NCCAM: National Center for Complementary and Alternative Medicine; TGA: Thermogravimetric analysis; FT-IR: Fourier transform infrared.

\section{Acknowledgements}

The authors are thankful to Trivedi Master Wellness, Trivedi Testimonials, and Trivedi Science for their sturdy support during this study. Authors would also like to acknowledge the entire team of MGV pharmacy college, Nashik for providing the instrumental facility, used in this study.

\section{References}

[1] Zulfiqar B, Abbasi NA, Ahmad T, Hafiz IA (2009) Effect of explant sources and different concentrations of plant growth regulators on in vitro shoot proliferation and rooting of avocado (Persea americana Mill.) cv. "Fuerte". Pak J Bot 41: 2333-2346.

[2] Saad AI, Elshahed AM (2012) Plant tissue culture media. Recent advances in plant in vitro culture.

[3] Trigiano RN, Gray DJ (1999) Plant tissue culture concepts and laboratory exercises. (2ndedn), CRC Press, New York.
[4] De Fossard R (1976) Tissue culture for plant propagation. Armidale: University of New England.

[5] George EF, Hall MA, Klerk GD (2007) Plant propagation by tissue culture. (3rdedn), Springer, Netherland.

[6] Murashige T, Skoog F (1962) A Revised medium for rapid growth and bio assays with tobacco tissue cultures. Physiol Plant 15: 473-497.

[7] Sridhar TM, Aswath CR (2014) Review on medicinal plants propagation: A comprehensive study on role of natural organic extracts in tissue culture medium. Am J Plant Sci 5: 30733088 .

[8] Rivera-Posada J, Caballes CF, Pratchett MS (2013) Lethal doses of oxbile, peptones and thiosulfate-citrate-bile-sucrose agar (TCBS) for Acanthaster planci: Exploring alternative population control options. Mar Pollut Bull 75: 133-139.

[9] Basu S, Pal A, Desai PK (2005) Quality control of culture media in a microbiology laboratory. Ind J Med Microbiol 23: 159-163.

[10] Trivedi MK, Patil S, Shettigar H, Singh R, Jana S (2015) An impact of biofield treatment on spectroscopic characterization of pharmaceutical compounds. Mod Chem Appl 3: 159.

[11] Trivedi MK, Nayak G, Patil S, Tallapragada RM, Jana S, et al. (2015) Bio-field treatment: An effective strategy to improve the quality of beef extract and meat infusion powder. J Nutr Food Sci 5: 389.

[12] Koithan M (2009) Introducing complementary and alternative therapies. J Nurse Pract 5: 18-20.

[13] Rubik B (2008) Measurement of the human biofield and other energetic instruments, Chapter 20 of energetics and spirituality by Lyn Freeman. http://www.faim.org/energymedicine/measurement-humanbiofield.html.

[14] Jahn RG, Dunne BJ (1988) Margins of reality: The role of consciousness in the physical world. San Diego, CA: Harcourt Brace Jovanovich.

[15] Rosch PJ (2009) Bioelectromagnetic and subtle energy medicine. The interface between mind and matter. Longevity, regeneration and optimal health, New York Academy of Science.

[16] Patil SA, Nayak GB, Barve SS, Tembe RP, Khan RR (2012) Impact of biofield treatment on growth and anatomical characteristics of Pogostemon cablin (Benth.). Biotechnology 11: 154-162.

[17] Sances F, Flora E, Patil S, Spence A, Shinde V (2013) Impact of biofield treatment on ginseng and organic blueberry yield. Agrivita J Agric Sci 35: 22-29.

[18] Trivedi MK, Patil S, Shettigar H, Mondal SC, Jana S (2015) An impact of biofield treatment: Antimycobacterial susceptibility potential using BACTEC 460/MGIT-TB system. Mycobact Dis 5: 189.

[19] Fultz B, Howe J (2013) Diffraction and the X-ray powder diffractometer. Transmission electron microscopy and diffractometry of materials. (4thedn), Springer-Verlag, Berlin, Heidelberg.

[20] Rehani BR, Joshi PB, Lad KN, Pratap A (2006) Crystallite size estimation of elemental and composite silver nano-powders using XRD principles. Indian J Pure Ap Phy 44: 157-161. 
[21] Purushotham E, Krishna NG (2012) X-ray determination of crystallite size and effect of lattice strain on Debye-Waller factors of platinum nano powders. Bull Mater Sci 36: 973976.

[22] Zhang K, Alexandrov IV, Kilmametov AR, Valiev RZ, Lu K (1997) The crystallite-size dependence of structural parameters in pure ultrafine-grained copper. J Phys D: Appl Phys 30: 3008-3015.

[23] Papangkorn K (2008) Metastable equilibrium solubility of various crystallinity carbonated apatites and human dental enamel under acidic conditions with and without the presence of solution fluoride. Proquest LLC, USA.

[24] DeVito SC, Farris CA (1997) Premanufacture notification: Chemistry assistance for submitters. John Wiley \& Sons, INC., New York, USA.

[25] Huang FY (2012) Thermal properties and thermal degradation of cellulose tri-stearate (CTs). Polymers 4: 1012-1024.

[26] Rudnik E (2010) Compostable polymer materials. Elsevier, Oxford, UK.
[27] Trivedi MK, Patil S, Mishra RK, Jana S (2015) Thermal and physical properties of biofield treated bile salt and proteose peptone. J Anal Bioanal Tech 6: 256.

[28] Pavia DL, Lampman GM, Kriz GS (2001) Introduction to spectroscopy. (3rdedn), Thomson Learning, Singapore.

[29] Smith BC (1998) Infrared spectral interpretation: A systematic approach. CRC Press.

[30] Miller FA, Wilkins CH (1952) Infrared spectra and characteristic frequencies of inorganic ions. Anal Chem 24: 1253-1294.

[31] Chaban GM, Huo WM, Lee TJ (2002) Theoretical study of infrared and Raman spectra of hydrated magnesium sulfate salts. The J Chem Phys 117: 2532-2537.

[32] Rao CNR, Venkataraghavan R, Kasturi TR (1964) Contribution to the infrared spectra of organosulphur compounds. Can J Chem 42: 36-42.

[33] Fayer MD (2010) Absolutely small: How quantum theory explains our everyday world. 